\title{
EFFECTS OF WEED CONTROL ON SEED YIELD AND FATTY OIL RATIO OF BLACK CUMIN (Nigella sativa L.)
}

\author{
Saliha KIRICI ${ }^{1}$, Tuncay CALISKAN², Rustu HATIPOGLU ${ }^{1}$, Veli CELIKTAS ${ }^{3}$, Hande OTU BORLU \\ ${ }^{1}$ Cukurova University, Faculty of Agriculture, Dep. of Field Crops, Adana, TURKEY \\ ${ }^{2}$ Ankara University, Kalecik Vocational School, Ankara, TURKEY \\ ${ }^{3}$ Amasya University, Suluova Vocational School, Amasya, TURKEY \\ ${ }^{4}$ Cukurova University, Faculty of Science and Literature, Adana, TURKEY \\ *Corresponding author: kirici@cu.edu.tr
}

Received: 05.10.2021

\begin{abstract}
Nigella sativa, also known as black cumin, is one of the medicinal plants, its seeds show a wide therapeutic potential, and they are used as spice in different kind of foods. The effects of different herbicides on yield and some yield components of Cameli Black cumin cultivar under Adana ecological conditions were investigated in this experiment that conducted between 2015-2016, 2016-2017 and 2017-2018 growing seasons in the Research and Application Area of Field Crops Department of Agricultural Faculty of Cukurova University. Three different herbicides were applied in nine different applications. Plant height, number of branches, number of capsules in the plant, seed yield and oil ratio differed according to application periods. The highest seed yield was obtained from the treatment of hand hoeing. Malondialdehyde and proline analysis were performed to detect oxidative stress and it was found that hand hoeing caused less stress in plants compared to other treatments. According to the results of the study, it was concluded that hand hoeing instead of herbicide application for the control of weeds in black cumin is more appropriate for yield and ecological perspective.
\end{abstract}

Keywords: Black cumin, morphological, herbicide, stress, malondialdehyde, proline.

\section{INTRODUCTION}

Black cumin seeds have been used in folk medicine for many years and are one of the widely known spice plants besides their therapeutic properties, it is used in folk medicine because of its urinary and milk enhancing, appetizing, gas and menstrual expectorant properties. Black cumin seeds are the most important part of the plant, and the seeds contain about \% 30-40 crude oil. The seeds also contain approximately $0.5-1.4 \%$ essential oil (Kucukemre 2009; Gutiérrez Prieto and Kırıc1, 2020). The seed essential oil and its main active constituent, thymoquinone, are reported to exhibited protective effect against many disases depending on its high antioxidant activity (Mariod et al., 2009). Currently, black cumin seed-producing countries are: India, Pakistan, Sri Lanka, Bangladesh, Nepal, Egypt, Syria, Saudi Arabia, Turkey, Iran, and Iraq (Haq et al., 2015). Black cumin is generally cultivated under dry farming conditions. Growing black cumin under these conditions often results in low seed yield and quality losses due to limited rainfall, the requirement to compete with weeds (Can et al., 2021). The production area as well as amount of the production had been increasing in the years and years. In the Turkey, the annual production of black cumin was 3.322 metric tons in 2018 crop production season from a harvested area of 3386,4 ha (Kirici et al., 2020). The demand of black cumin seed and its oil has also been increasing both in local and national markets for consumption purpose. Black cumin Seed Oil Market size was over USD 15 million in 2018 and industry expects significant gains by 2025 (Ahuja and Singh, 2019).

Recently, the chemical control against to weeds has brought some problems such as environmental pollution and resistance to herbicides. Weeds are in competition with the cultivated plants in terms of growing area, nutrients, water, light and carbon dioxide. When any of these substances is limited by weeds, the growth of the culture plant begins to slow down. Weeds cause a decrease in the amount of crop to be harvested and consequently a decrease in yield (Aldrich and Kremer, 1997). Plants are exposed to biotic and abiotic stresses in natural environments during their whole life circle. The frequently-occuring abiotic stresses includes extreme temperature, high salinity, excessive light, water deprivation, pollutants such as ozone and herbicides, high concentration of heavy metals, excessive ultra violet radiation and so on. Malondialdehyde (MDA) is a widely used marker of oxidative lipid injury caused by environmental stress (Kong et al., 2016). MDA accumulation increased with the increase of the herbicide dosage (Jin et al., 2010). In plants, Prolin accumulation has been reported to occur after salt, drought, high temperature, 
low temperature, heavy metal, pathogen infection, anaerobiosis, nutrient deficiency, atmospheric pollution and UV irradiation (Verbruggen and Hermans, 2008).

In order to achieve the yield and quality targets, weed control is a necessity and we need to follow the ecological balance as much as possible in this process. The aim of this research was to determine effects of some of the weed control methods such as herbicide use and hand hoeing on the seed yield, yield components and oil content of the seeds as well as proline and malondialdehyde content of the plant in black cumin

\section{MATERIALS and METHODS}

Cameli cultivar which was developed and registered at 8 April 2014 by the Transitional Zone Agricultural Research Institute (Eskisehir) was used in this study.

\section{Cultivating applications}

The field experiments were conducted at research area of Department of Field Crops, University of Cukurova during winter season for three years. Experimental site was located in Southern part of Turkey, it has a Mediterranean climate zone. Monthly average temperature and rainfall during the experimental years are presented in Table 1 . Soil samples were taken randomly from $0-30$ and $30-60 \mathrm{~cm}$ depth. It has been determined that the soils of the experimental area have loamy $(42.4 \%$ and $46.3 \%)$ and clay (34.7\% and $32.5 \%)$ texture, their $\mathrm{pH}(7.8$ and 7.7$)$ and salt

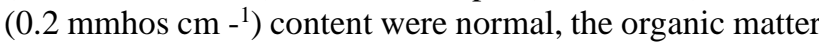
content $(1.1 \%$ and $0.9 \%)$ was low, and the phosphorus level (108 and $63 \mathrm{~kg} \mathrm{ha-}^{1}$ ) and potasium level (659 and 545 $\left.\mathrm{kg} \mathrm{ha-}{ }^{1}\right)$ were sufficient. $\mathrm{Fe}, \mathrm{Zn} \mathrm{Mn}$ and $\mathrm{Cu}$ contents were 3.7 and 3.5, 0.3 and 0.3, 8.9 and 8.1 and 1.2 and $1.0 \mathrm{mg} \mathrm{kg-}$ 1 , respectively.

Table 1. Monthly average temperature and rainfall values for the experiment area during the experimental

\begin{tabular}{lccccccccc}
\hline Years & November & December & January & February & March & April & May & June & \\
\hline \multicolumn{2}{l}{ Average Temperature $\left({ }^{\circ} \mathrm{C}\right)$} & & & & & & & & Mean \\
$2015-2016$ & 17.5 & 11.8 & 8.7 & 13.9 & 15.7 & 20.5 & 21.6 & 27.1 & 17.1 \\
$2016-2017$ & 15.6 & 9.0 & 8.7 & 10.7 & 15.2 & 18.5 & 21.8 & 26.2 & 15.7 \\
$2017-2018$ & 15.9 & 12.6 & 10.5 & 13.5 & 16.8 & 20.1 & 24.4 & 26.4 & 17.5 \\
Rainfall (mm) & & & & & & & & & Total \\
$2015-2016$ & 10.5 & 0.6 & 138.4 & 83.1 & 67.1 & 36.6 & 87.9 & 45.6 & 465.2 \\
$2016-2017$ & 11.9 & 216.3 & 52 & 0.8 & 65.4 & 65.9 & 45.9 & 17.3 & 475.5 \\
$2017-2018$ & 122.7 & 33.0 & 324.3 & 64.8 & 40.1 & 35.0 & 29.5 & 25.6 & 675.0 \\
\hline
\end{tabular}

*Data were taken from Adana Meteorology Station

The experiment carried out in randomized complete block design with four replications. The plot size was $3 \times 1.25 \mathrm{~m}$ (6 row per plot). Seeds were sown at the last week of November and harvest dates were varied according to years (Table 2). $15 \mathrm{~kg} \mathrm{ha}^{-1}$ seeds per hectare were sown by hand to a depth of 1-2 cm. Fertilization was carried out as pure $40 \mathrm{~kg}$ ha- ${ }^{1} \mathrm{P}$ (Triple Super Phosphate) and $60 \mathrm{~kg}$ ha${ }^{1} \mathrm{~N}$ (Ammonium Nitrate) during seed sowing. Seedlings were thinned out to $10 \mathrm{~cm}$ within row at two weeks after emergence. The first irrigation was carried out after sowing. Subsequent irrigations were done when it was needed.

Table 2. Some imported growing dates of black cumin experiment

\begin{tabular}{llll}
\hline & I. Year & II. Year & III. Year \\
\hline Sowing date & $26 / 11 / 2015$ & $28 / 11 / 2016$ & $15 / 11 / 2017$ \\
Emergence date & $18 / 12 / 2015$ & $03 / 01 / 2017$ & $03 / 12 / 2017$ \\
Flowering date & $01 / 04 / 2016$ & $15 / 04 / 2017$ & $04 / 04 / 2018$ \\
Harvest date & $13 / 06 / 2016$ & 19.07 .2017 & $07 / 06 / 2018$ \\
Vegetation period & 200 days & 229 days & 203 days \\
\hline
\end{tabular}

\section{Hoeing and herbicide applications}

In the experiment, Farmson super (active ingred is $50 \mathrm{~g}$ $1{ }^{1}$ Quizalofop-p-ethyl) as pre-sowing herbicide, Fusilade Forte (active ingred is $150 \mathrm{~g} \mathrm{l}^{-1}$ Fluazifop-P-Butyl) as preemergent herbicide and Challenge SC 600 (active ingred is $600 \mathrm{~g}^{1-}{ }^{1}$ Aclonifen) as post- emergent herbicide were tested. The weed control treatments were as following 1) application of pre sowing herbicide 2) application of pre emergent herbicide 3) application of post emergent herbicide 4) application of pre-sowing herbicide+ preemergent herbicide 5) application of pre-sowing herbicide+ post emergent herbicide 6) application of pre emergent herbicide +post emergent herbicide 7) application of pre sowing herbicide + pre- emergent herbicide + post emergent herbicide 8) hand hoeing 9) control with without weed control. Biomass of weeds was weighted as total aboveground dry weight for each plot at harvesting time of black cumin.

\section{Determination of yield and morphological properties}

When the fruit peels began to darken and crackings were seen, plants were harvested by hand. Ten plants were selected at maturity randomly from each plot for recording plant height $(\mathrm{cm})$, number of branches per plant, number of 
capsules per plant. Two samples of 1000 seeds were taken from each plot to record 1000-seed weight. Seed yield was recorded with middle four row on per plot basis and was converted to $\mathrm{kg} \mathrm{ha}^{-1}$. Fatty oil ratio was determined according to The American Oil Chemists Society (AOCS) method (AOCD, 1993). 5 grams of whole seeds were milled and the extraction was by soxhlet apparatus with nhexan for 6 hours, after extraction, the solvent was evaporated, than weighed. The seed oil content was reported as the mass percent (crude oil weight $(\mathrm{g}) / \mathrm{ground}$ seeds weight $(\mathrm{g}) \times 100)$.

\section{Proline analyse}

Proline content was determined under herbicide applying and hoeing stress according to the method of (Bates 1973) on total harvested vegetative parts of plants at 2018. In the case, $500 \mathrm{mg}$ of fresh plant material was homogenized with $3 \%$ sulpho salicylic acid and filtered at blue band filter paper. Then $2 \mathrm{ml}$ sample was put in a glass tube, then $2 \mathrm{ml}$ ninhydrin solution (which contains ninhydrin, ortophosphoric acid and acetic acid) and $2 \mathrm{ml}$ acetic acid were added into the tube. After that it was incubated in boiling water for one hour, samples put into ice bath. Then, $4 \mathrm{ml}$ toluene put on the samples and read at $520 \mathrm{~nm}$ spectrophotometrically. Proline content of samples was calculated according to standard curve which drowns with L-proline.

\section{Malondialdehyde analyse}

Lipid peroxidation of membranes was estimated by measuring malondialdehyde content according to modified Hodges et al.'s (1999) protokol. Malonialdehyde content was determined at 2018. $500 \mathrm{mg}$ dry leaf material was extracted with $80 \%$ ethyl alcohol and santrifuged 10 minutes at $3000 \mathrm{~g}$. After this, treatment was conducted as two stage. For first stage $2 \mathrm{ml}$ TBA (-) solution which contains $20 \%$ TCA and $0.01 \%$ BHT in it; samples incubated in $95^{\circ} \mathrm{C}$ waterbath for 25 minutes; after ice bath santrifuged again 15 minutes at $3000 \mathrm{~g}$. Distinctively from first stage, (+) TBA solution was used instead of (-) TBA solution, which had also $0,65 \%$ in it, used in second stage. First samples read at 532 and $600 \mathrm{~nm}$; second stage samples read at 440, 532 and $600 \mathrm{~nm}$ spectrophotometrically. Absorbans values put into formulas below and MDA content calculated.

$$
\text { 1. [(ABS } \left.{ }_{532}+\mathrm{TBA}\right)-\left(\mathrm{ABS}{ }_{600}+\mathrm{TBA}\right)-\left(\mathrm{ABS}{ }_{532}\right. \text {-TBA)- }
$$
$\left.\left(\mathrm{ABS}_{600}-\mathrm{TBA}\right)\right]=\mathrm{A}$

$$
\begin{gathered}
\text { 2. } \left.\left[\left(\mathrm{ABS}_{440}+\mathrm{TBA}^{-} \mathrm{ABS}_{600}+\mathrm{TBA}\right) / 0.0571\right)\right]=\mathrm{B} \\
\text { 3. } \mathrm{nmol} \mathrm{MDA} / \mathrm{ml}=(\mathrm{A}-\mathrm{B}) / 157000) / 10^{6} \\
\text { Statistical Analyses }
\end{gathered}
$$

The data obtained from the study were analyzed for variance by using the MSTAT - C statistical package program according to the randomized complete block design, and standard deviation values were calculated for Proline and MDA analysis. The differences between the mean values were compared by using Duncan's new multiple range test (MRT) at 5\% significance level (Steel and Torrie, 1980).

\section{RESULTS AND DISCUSSION}

Results of statistical analysis for the effects of experimental factors (yaer and treatments) on yield and

\begin{tabular}{|c|c|c|c|c|c|c|c|c|}
\hline $\begin{array}{l}\text { Experimental } \\
\text { Factors }\end{array}$ & $\mathrm{DF}$ & $\begin{array}{l}\text { Weed } \\
\text { Weights } \\
\left(\mathrm{kg} \mathrm{ha}^{1}\right)\end{array}$ & $\begin{array}{l}\text { Plant } \\
\text { height } \\
(\mathrm{cm})\end{array}$ & $\begin{array}{l}\text { Number } \\
\text { of } \\
\text { branches }\end{array}$ & $\begin{array}{l}\text { Number } \\
\text { of } \\
\text { capsules } \\
\text { Mean Squ }\end{array}$ & $\begin{array}{l}\text { Seed yield } \\
\left(\mathrm{kg} \mathrm{ha}^{-1}\right) \\
\text { s }\end{array}$ & $\begin{array}{l}\text { Thousand } \\
\text { Seed W. } \\
\text { (g) }\end{array}$ & $\begin{array}{l}\text { Fatty oil } \\
\text { Ratio } \\
(\%)\end{array}$ \\
\hline Year & 2 & $898.14 * *$ & $6059.79 * *$ & $0.62 * *$ & $429.06^{* *}$ & $444519.01 * *$ & $1.84 * *$ & $12.21 *$ \\
\hline Error & 6 & 0.49 & 3.69 & 0.02 & 0.05 & 7036.43 & 0.03 & 1.26 \\
\hline Treatment & 8 & $107.14 * *$ & $160.01 * *$ & $0.82 * *$ & $120.19 * *$ & $591131.54 * *$ & $0.15^{* *}$ & $43.38 * *$ \\
\hline $\begin{array}{l}\text { Year x } \\
\text { Treatment }\end{array}$ & 16 & $34.73 * *$ & $41.14 * *$ & $0.41 * *$ & $19.68 * *$ & $27673.03 * *$ & 0.03 & $6.93 *$ \\
\hline Error & 48 & 0.60 & 8.24 & 0.14 & 0.29 & 8597.09 & 0.02 & 3.20 \\
\hline C.V.(\%) & & 9.97 & 6.32 & 13.38 & 7.17 & 36.40 & 7.48 & 5.26 \\
\hline
\end{tabular}
some yield components of black cumin with $\mathrm{P}$ values were given in Table 3.

Table 3. ANOVA results for some yield and quality traits of black cumin

$*$ and $* *$ are significant at $\mathrm{p}=0.05$ and $\mathrm{p}=0.01$, respectively.

\section{Weed species encountered in the experimental plots}

Weed species encountered in the experimental plots are given in Table 4. As seen in the table, totaly 23 species of weeds from 15 plant families were determined in the experimental plots during the experimental years. Cyperus rotundas, Portulaca oleracea, Amaranthus retrqflexus, Prosophis farcta, Convolvulus arvensis, Xanthium strumarium, Cynodon dactylon were found the most intense in cotton, corn and soybean fields in Cukurova region (Gonen, 1999). 
Table 4. Determined weed species of black cumin in experiment years.

\begin{tabular}{llll}
\hline Family & Species & Family & Species \\
\hline Alliaceae & Allium sp. & Brassicaceae & Sinapis arvensis \\
Poaceae & Alopecurus myosuroides & Boraginaceae & Echium sp. \\
& Avena sterilis & Lamiaceae & Lamium purpureum \\
& Avena fatua & Polygonaceae & Polygonum aviculare \\
Asteraceae & Centaurea $\mathrm{sp}$. & Ranunculaceae & Ranunculus sp. \\
& Matricaria sp. & Ranunculaceae & Ranunculus sp. \\
Amaranthaceae & Sonchus sp. & & Lathyrus annuus \\
Convolvulaceae & Chenopodium album & Fabaceae & Medicago sp. \\
Apiaceae & Convolvulus arvensis & & Medicago scutellata \\
Geraniaceae & Daucus carota & & Vicia narbonensis \\
& Geranium rotundifolium & Papaveraceae & Papaver rhoeas \\
& & & Fumaria officinalis \\
\hline
\end{tabular}

Weeds are one of the factors which negatively affect the quality and yield of crops. Continuous changes in weed flora takes place either by climatic change or through the introduction of new weed species into the agro ecosystem. Therefore, comparative weed surveys were carried out in Cukurova Region, across three provinces namely Adana, Mersin and Osmaniye, and determined the most troublesome weed species in corn fields, as a result, total 42 weed species belonging to 19 families were identified (Hancerli and Uygur, 2017). Among the identified weed species, Chenopodium album, Convolvulus arvensis, Papaver rhoeas, Avena sterilis, Polygonum aviculare, Medicago sp. and Vicia sp. were common plants with our research in spite of different growing period. Sterile wild oat (Avena sterilis L.) and wild mustard (Sinapis arvensis L.) were determined as the main harmful weeds in wheat fields in Cukurova region (Tunk and Uygur, 2020). The herbicide doses should be established for weeds and recommended according to the their economic threshold level in a wheat field in the region for environmental protection, food safety, herbicide resistance problem.

\section{Weed Biomas yield in the experimental plots}

Weed biomass yield determined in the experimental plots treated with different weed control treatments in the experimental years are given in the Table 5. Weed control method significantly affected the weed biomass yield in all the experiemental years (Table 3 ).

Table 5. Weed biomass yields (t/ha) in the experimental plots treated with different weed control methods in experiment years (Pr.S= pre-sowing, Pr.E=pre-emergence, Po.E= post-emergence).

\begin{tabular}{|c|c|c|c|c|}
\hline \multirow[b]{2}{*}{ Treatments } & \multicolumn{4}{|c|}{ Weed Weights $\left(\mathrm{kg} \mathrm{ha}^{1}{ }^{1}\right)$} \\
\hline & $2016 *$ & $2017 * *$ & $2018^{*}$ & Means of years** \\
\hline Control & $5.89 b^{*}$ & $6.37 \mathrm{a}$ & $24.52 \mathrm{a}$ & $12.26 \mathrm{a}$ \\
\hline Pr.S. & $5.82 \mathrm{~b}$ & $4.77 \mathrm{~cd}$ & $13.90 \mathrm{~d}$ & 8.16 de \\
\hline Pr.E. & $4.97 \mathrm{c}$ & $4.80 \mathrm{~cd}$ & $14.13 \mathrm{~d}$ & $7.94 \mathrm{e}$ \\
\hline Po. E. & $4.51 \mathrm{~d}$ & $4.88 \mathrm{c}$ & $20.92 b$ & $10.10 \mathrm{~b}$ \\
\hline Pr.S+Pr.E. & $6.65 \mathrm{a}$ & $4.80 \mathrm{~cd}$ & $13.95 \mathrm{~d}$ & 8.46 cde \\
\hline Pr.S+Po.E. & $3.48 \mathrm{e}$ & $4.67 \mathrm{de}$ & $7.81 \mathrm{e}$ & $5.32 \mathrm{f}$ \\
\hline Pr.E.+Po.E. & $3.39 \mathrm{e}$ & $5.70 \mathrm{~b}$ & $17.31 \mathrm{c}$ & $8.82 \mathrm{~cd}$ \\
\hline Pre.S.+Pre.E.+Po.E. & $4.93 \mathrm{c}$ & $4.60 \mathrm{e}$ & $17.48 \mathrm{c}$ & $9.00 \mathrm{c}$ \\
\hline Manuel hoeing & 0 & 0 & 0 & 0 \\
\hline Means & $4.40 \mathrm{~b}$ & $4.51 \mathrm{~b}$ & $14.45 \mathrm{a}$ & \\
\hline
\end{tabular}

*: Significant at $\mathrm{p}=0.05$, **: Significant at $\mathrm{p}=0.01$. Mean values with the same letter are not statistically significant different from each other according to the Duncan test at $\mathrm{P} \leq 0.05$

At the harvest of the black cumin, the highest weed biomass yield was determined in the plots treated with presowing+pre-emergent herbicide application in the first year. The treatments of pre-sowing+post-emergent herbice application and pro-emergent+post emergent herbicide application resulted in significantly lower weed biomass yield than the other herbicide treatment. Application of pre-sowing herbicide did not provide any weed control because averaged value of weed biomass yield for this herbicide treatment was not statistically significant different than the control treatment with without weed control. In the second year, the most effective weed control treatment among the herbicide treatments was the application of pre-sowing+pre-emergent+ post emergent herbicide no weed biomass was determined in the manuelly hoed plots. It was reported that different climate conditions had affected herbicide activity and avaliability at lower doses, by Kudsk and Kristenden (1992). 


\section{Morphological properties, seed yield and oil ratio}

In the years of 2016, 2017 and 2018, mean values of plant height, number of branches and capsules and seed yield in black cumin grown under different weed control treatment are shown in Table 6.

In the first year experiment, averaged value of plant height in the hand hoed plots was significantly higher than those in the plots treated with other weed control treatments. Application of pre-sowing+pro-emergent+post emergent herbicides resulted in a plant height being significantly higher than the control treatment and other herbicide treatments with the exception of the treatment of pre-sowing+post emergent herbicides. In the second year, the plants in the manually hoed plots showed significantly higher averaged value of plant height than the other weed control treatments. In the third year, the averaged plant heigts in the herbicide treated plots with the exceptions of the applications of alone pre-emergence, pre-sowing herbicide +pre-emergent herbicide and pre-emergent + post emergent herbicides were not statistically significant different from that in the manually hoed plots. Plant height values determined in the study are compatible with those reported by Kizil et al. (2008) and Tuncturk et al. (2005).

The effects of the treatments on the number of branches of black cumin were statistically significant in the first and third years, but not in the second year. In the first year, the treatment of manually hoeing gave significantly higher branch number per plant than all of the other treatments with the exception of the treatment of pre-emergent+ post emergent herbicides apllication. In the third year, the treatment of manually hand hoeing gave significantly higher branch number than all of the other weed control treatments with the exception of the treatment of presowing+pre-emergent+post- emergent herbicide application. The results of the study showed that black cumin could not compete with weeds in plots which had dense weed population and therefore the number of branches decreased. It was stated that the number of branches in black cumin was significantly affected by weed competition periods (Hussain et al., 2009). The values of branch number per plant determined in the study are compatible with those reported by Ozel et al. (2002 and 2009).

Analyses of the data related to the number of capsules per plant showed that the weed control treatments significantly affected the mentioned characteristic of black cumin in all of the experimental years (Table 3). Manuel hoeing resulted in significatly higher capsule number per plant than all of the other weed control treatments in all of the experimental years. In the first year, all of the herbicide treatmens with the exception of the treatment of pre-sowing herbicide application gave statistically significant higher capsule number per plant than the control treatment. In the second year, alone applications of pre-sowing and preemergent herbicides were not statistically significant different from control treatment while post-emergent herbicide application resulted in significantly higher capsule number per plant than the control treatment. In the third year, application of post emergent herbicide and combined applications of pre sowing+pre-emergent herbicides, pre-emergent+post-emergent herbicides and pre-sowing+pre-emergent+post-emergent herbicides resulted in higher capsule number per plant than control treatment.

In all of the experimental years, manuelly hoeing tretament gave higher seed yield than all of the other weed control treatments. In the first and second year, combined application of pre-sowing+pre-emergent+post-emergent herbicides resulted in significantly higher seed yield than the other herbicide treatment as well as control treatment while combined application of pre-sowing+post-emergeng herbicides gave higher seed yield than the other herbicide tretment and control treatment in the third year. Seed yield negatively effected with weed biomass, because lowest one obtained from high biomass weight according to mean of years. Meena et al. (2014) have determined that the application of herbicides before emergence and removal of weeds by hand 45 days after planting is the best way both economically and in terms of high yields. Hussain et al. (2009) stated that weed control in black cumin provided $69.41 \%$ increase in seed yield and weed competition caused significant decreases in seed yield. Nadeem et al. (2013) stated that, maximum seed yield was obtained from the plots where weeds were removed, there was a linear decrease depending on weed competition duration, it was necessary to control in 40 days after emergence which is critic stage to avoid degradation in black cumin. Becides, the herbicide treatments had a negative impact on photosynthesis (Saladin et al, 2003). Seed yields obtained in this study were higher than those reported by D'antuono et al (2002) and Ozel et al (2002). Weed competition for total growing season reduced the grain yield of black seed by $87 \%$, compared with entire weed-free treatment (Seyyedi et al., 2016). Grain yield losses due to uncontrolled weed growth, it had direct correlation with weed competition (Korav et al., 2018). 
Table 6. Morphological properties and seed yield in black cumin grown under different weed control treatments in experiment years (Pr.S= pre-sowing, Pr.E=pre-emergence, Po.E= post-emergence).

\begin{tabular}{|c|c|c|c|c|c|c|c|c|}
\hline \multirow[b]{2}{*}{ Treatments } & \multicolumn{4}{|c|}{ Plant Height $(\mathrm{cm})$} & \multicolumn{4}{|c|}{ Number of Branches (per plant) } \\
\hline & $2016 * *$ & $2017^{*}$ & $2018 *$ & Mean of Years** & $2016^{* *}$ & 2017 & $2018^{*}$ & Mean of Years** \\
\hline Control & $24.1 \mathrm{~d}$ & $48.9 \mathrm{e}$ & $49.0 \mathrm{bc}$ & $40.7 \mathrm{~d}$ & $2.1 \mathrm{c}$ & 2.6 & $2.9 \mathrm{bc}$ & $2.5 \mathrm{~cd}$ \\
\hline Pr.Sowing & $23.5 \mathrm{~d}$ & $53.0 \mathrm{~d}$ & $57.8 \mathrm{a}$ & $44.7 \mathrm{c}$ & $2.3 \mathrm{bc}$ & 2.8 & $2.9 \mathrm{bc}$ & $2.7 \mathrm{bcd}$ \\
\hline Pr.Emergence & $24.4 \mathrm{~d}$ & $55.3 \mathrm{~b}$ & $45.1 \mathrm{c}$ & $41.6 \mathrm{~d}$ & $2.4 \mathrm{bc}$ & 3.0 & $1.8 \mathrm{~d}$ & $2.4 \mathrm{~d}$ \\
\hline Post Emergence & $25.2 \mathrm{~d}$ & $54.5 \mathrm{bc}$ & $58.2 \mathrm{a}$ & $45.9 \mathrm{c}$ & $2.6 \mathrm{bc}$ & 3.2 & $2.4 \mathrm{~cd}$ & $2.7 \mathrm{bcd}$ \\
\hline Pr.S+Pr.E & $24.6 \mathrm{~d}$ & $50.1 \mathrm{e}$ & $50.4 \mathrm{~b}$ & $41.7 \mathrm{~d}$ & $2.7 \mathrm{bc}$ & 3.1 & $2.7 \mathrm{bcd}$ & $2.8 \mathrm{bc}$ \\
\hline Pr.S+Po.E & $28.6 \mathrm{bc}$ & $54.2 \mathrm{bc}$ & $57.7 \mathrm{a}$ & $46.8 \mathrm{bc}$ & $2.7 \mathrm{bc}$ & 3.1 & $2.6 \mathrm{bcd}$ & $2.8 \mathrm{bc}$ \\
\hline Pr.E+Po.E & $28.0 \mathrm{c}$ & $53.1 \mathrm{~cd}$ & $52.3 b$ & $44.5 \mathrm{c}$ & $2.9 \mathrm{ab}$ & 3.0 & $2.3 \mathrm{~cd}$ & $2.7 \mathrm{bcd}$ \\
\hline Pr.S+Pr.E+Po.E & $31.1 \mathrm{~b}$ & $54.7 \mathrm{bc}$ & $61.2 \mathrm{a}$ & $49.0 \mathrm{~b}$ & $2.8 \mathrm{~b}$ & 2.9 & $3.4 \mathrm{ab}$ & $3.0 \mathrm{~b}$ \\
\hline Manual hoeing & $44.0 \mathrm{a}$ & $57.7 \mathrm{a}$ & $60.5 \mathrm{a}$ & $54.1 \mathrm{a}$ & $3.5 \mathrm{a}$ & 3.0 & $3.8 \mathrm{a}$ & $3.4 \mathrm{a}$ \\
\hline \multirow[t]{3}{*}{ Mean } & $28.2 \mathrm{~b}$ & $53.5 \mathrm{a}$ & $54.7 \mathrm{a}$ & & $2.6 \mathrm{~b}$ & $2.9 \mathrm{a}$ & $2.7 \mathrm{~b}$ & \\
\hline & \multicolumn{4}{|c|}{ Number of Capsules (per plant) } & \multicolumn{4}{|c|}{ Seed Yield $\left(\mathrm{kg} \mathrm{ha-}^{-1}\right)$} \\
\hline & $2016 * *$ & $2017 *$ & $2018 *$ & Mean of Years** & $2016 * *$ & $2017 *$ & $2018 *$ & Mean of Years** \\
\hline Control & $5.5 \mathrm{~g}$ & $5.1 \mathrm{~d}$ & $1.9 \mathrm{c}$ & $4.2 \mathrm{f}$ & $13.7 \mathrm{~g}$ & $94.0 \mathrm{~g}$ & $59.3 \mathrm{~d}$ & $77.7 \mathrm{~d}$ \\
\hline Pr.Sowing & $6.9 \mathrm{fg}$ & $6.5 \mathrm{~cd}$ & $2.3 \mathrm{c}$ & $5.2 \mathrm{e}$ & $35.3 \mathrm{f}$ & $244.0 \mathrm{f}$ & $146.5 \mathrm{c}$ & $141.9 \mathrm{~cd}$ \\
\hline Pr.Emergence & $7.6 \mathrm{ef}$ & $\begin{array}{l}7.2 \\
\text { bcd }\end{array}$ & $2.3 \mathrm{c}$ & $5.7 \mathrm{e}$ & $34.3 \mathrm{f}$ & $237.0 \mathrm{f}$ & $154.0 \mathrm{c}$ & $142.1 \mathrm{~cd}$ \\
\hline Post Emergence & $10.0 \mathrm{~cd}$ & $9.4 \mathrm{~b}$ & $3.2 \mathrm{~b}$ & $7.4 \mathrm{c}$ & $62.8 \mathrm{~d}$ & $332.0 \mathrm{~cd}$ & $163.6 \mathrm{c}$ & $186.1 \mathrm{bc}$ \\
\hline Pr.S+Pr.E & $8.8 \mathrm{de}$ & $6.7 \mathrm{~cd}$ & $3.4 \mathrm{~b}$ & $6.3 \mathrm{~d}$ & $50.5 \mathrm{e}$ & $267.0 \mathrm{ef}$ & $140.3 \mathrm{c}$ & $152.6 \mathrm{c}$ \\
\hline Pr.S+Po.E & $10.9 \mathrm{c}$ & $8.3 \mathrm{bc}$ & $2.6 \mathrm{c}$ & $7.3 \mathrm{c}$ & $143.5 \mathrm{c}$ & $368.0 \mathrm{c}$ & $\begin{array}{c}279.7 \\
\mathrm{~b}\end{array}$ & $263.7 \mathrm{~b}$ \\
\hline Pr.E+Po.E & $10.4 \mathrm{~cd}$ & $7.9 \mathrm{bc}$ & $3.2 \mathrm{~b}$ & $7.1 \mathrm{c}$ & $69.8 \mathrm{~d}$ & $300.0 \mathrm{de}$ & $125.8 \mathrm{c}$ & $165.2 \mathrm{c}$ \\
\hline Pr.S+Pr.E+Po.E & $14.3 \mathrm{~b}$ & $7.8 \mathrm{bc}$ & $3.7 \mathrm{~b}$ & $8.6 \mathrm{~b}$ & $199.0 \mathrm{~b}$ & $435.0 \mathrm{~b}$ & $174.0 \mathrm{c}$ & $269.3 \mathrm{~b}$ \\
\hline Manual hoeing & $26.9 \mathrm{a}$ & $15.8 \mathrm{a}$ & $7.4 \mathrm{a}$ & $16.7 \mathrm{a}$ & $767.6 \mathrm{a}$ & $1013.0 \mathrm{a}$ & $666.7 \mathrm{a}$ & $915.8 \mathrm{a}$ \\
\hline Mean & $11.2 \mathrm{a}$ & $8.3 \mathrm{~b}$ & $3.3 \mathrm{c}$ & & $153.1 \mathrm{c}$ & 398.9 a & $\begin{array}{c}212.2 \\
b\end{array}$ & \\
\hline
\end{tabular}

*: Significant at $\mathrm{p}=0.05, * *$ : Significant at $\mathrm{p}=0.01$. Mean values with the same letter are not statistically significant different from each other according to the Duncan test at $\mathrm{P} \leq 0.05$

The effects of treatments on thousand seed weight was only found significant in second year (Table 7). In that year, highest thousand seed weight $(2.65 \mathrm{~g})$ was obtained from the treatment of pre-emergent herbicide application. However, the values of thousand seed weight for the treatments of pre-sowing herbicide applications, presowing+post-emergent herbicie application, premeregent+pot-emergent herbicide applications as well as manuelly hoeing were not statistically significant different from that of pre-emergent herbicide application. Hussain et al. (2009) have also found that thousand grain weight was significantly influenced by weed competition period. The values of thousand grain weight determined in this study results were compatible with those reported by Tuncturk et al. (2005) and Ozel et al. (2009) while the values were lower than determined by Ozel et al. (2002) and Abdolrahimi et al. (2012) results. Differences in thousand seed weight of black cumin in different researches can be due to differences in genotype, ecological conditions and growing technique among the researches.

The effect of weed control treatments on fatty oil content of black cumin seeds was found statistically significant different in all years (Table 7). Fatty oil content of seeds was changed between $28.5 \%$ and $36.2 \%$ in first year, $32.7 \%$ and $36.1 \%$ in second year and $26.7 \%$ and
$36.5 \%$ in third year (Table 7). In the first year, seeds from the plots with the treatment of pre-sowing+pro-emergent herbicide application showed significantly lower oil content than all of the other weed control treatment with the exception of control treatment. In the second year, treatments of pre-emergent herbicide aplication and presowing+pre-emergent herbicide application resulted in significantly lower oil content than the other weed control treatments with the exception of control treatment. In the third year, the treatments of pre-sowing+pre-emergent herbicide application and pre-emegent+post emergent herbicide application caused significantly lower oil content than the other herbicide treatments. Hussain et al. (2009) emphasized that, oil content of seeds in black cumin was decreased with weed competition and this situation may be resulted from the competition between crop plant and weed for environmental conditions and nutrient elements, thus the crop had lower photosynthesis activity and reduced oil content. Gutiérrez Prieto and Kırıc1 (2020) stated that oil content of black cumin seeds which had been changed between $32.0 \%$ and $36.33 \%$ in Cukurova. Kalcin (2003) reported that oil content of Nigella sativa and Nigella damascena $\mathrm{L}$ had been changed between $28.08 \%$ and $34.29 \%$ in Ankara conditions. 
Table 7. Thousand seed weight and fatty oil ratio (\%) in black cumin grown under different weed control treatments in experiment years $(\operatorname{Pr} . \mathrm{S}=$ pre-sowing, Pr.E=pre-emergence, $\mathrm{Po} . \mathrm{E}=$ post-emergence) .

\begin{tabular}{lccclcllll}
\hline & \multicolumn{4}{c}{ Thousand Seed Weight $(\mathrm{g})$} & \multicolumn{4}{c}{ Fatty Oil Ratio (\%) } \\
\cline { 2 - 8 } Treatments & 2016 & $2017^{* *}$ & 2018 & Mean of Years** & $2016^{*}$ & $2017^{*}$ & $2018^{*}$ & Mean of Years* \\
\hline Control & 2.08 & $2.32 \mathrm{~d}$ & 1.67 & $2.02 \mathrm{~d}$ & $28.5 \mathrm{c}$ & $32.6 \mathrm{c}$ & $26.7 \mathrm{c}$ & $29.3 \mathrm{c}$ \\
Pr.Sowing & 2.38 & $2.58 \mathrm{ab}$ & 2.17 & $2.37 \mathrm{abc}$ & $36.2 \mathrm{a}$ & $36.1 \mathrm{a}$ & $36.5 \mathrm{a}$ & $36.3 \mathrm{a}$ \\
Pr.Emergence & 2.40 & $2.65 \mathrm{a}$ & 2.12 & $2.39 \mathrm{ab}$ & $34.8 \mathrm{a}$ & $32.3 \mathrm{c}$ & $36.0 \mathrm{a}$ & $34.4 \mathrm{a}$ \\
Post Emergence & 2.31 & $2.49 \mathrm{bc}$ & 2.17 & $2.43 \mathrm{a}$ & $35.3 \mathrm{a}$ & $34.2 \mathrm{~b}$ & $34.6 \mathrm{a}$ & $34.7 \mathrm{a}$ \\
Pr.S+Pr.E & 2.19 & $2.41 \mathrm{c}$ & 2.00 & $2.20 \mathrm{c}$ & $32.6 \mathrm{~b}$ & $32.7 \mathrm{c}$ & $29.5 \mathrm{~b}$ & $31.6 \mathrm{~b}$ \\
Pr.S+Po.E & 2.37 & $2.54 \mathrm{ab}$ & 2.25 & $2.39 \mathrm{ab}$ & $34.8 \mathrm{a}$ & $35.5 \mathrm{a}$ & $35.3 \mathrm{a}$ & $35.2 \mathrm{a}$ \\
Pr.E+Po.E & 2.23 & $2.64 \mathrm{a}$ & 1.75 & $2.21 \mathrm{c}$ & $35.4 \mathrm{a}$ & $36.0 \mathrm{a}$ & $31.9 \mathrm{~b}$ & $34.4 \mathrm{a}$ \\
Pr.S+Pr.E+Po.E & 2.30 & $2.49 \mathrm{bc}$ & 2.00 & $2.24 \mathrm{bc}$ & $35.3 \mathrm{a}$ & $35.6 \mathrm{a}$ & $34.9 \mathrm{a}$ & $35.3 \mathrm{a}$ \\
Manual hoeing & 2.35 & $2.52 \mathrm{abc}$ & 2.08 & $2.29 \mathrm{abc}$ & $35.7 \mathrm{a}$ & $35.8 \mathrm{a}$ & $34.0 \mathrm{ab}$ & $35.2 \mathrm{a}$ \\
Mean & $2.28 \mathrm{~b}$ & $2.54 \mathrm{a}$ & $2.0 \mathrm{c}$ & & $34.3 \mathrm{a}$ & $34.5 \mathrm{a}$ & $33.3 \mathrm{~b}$ & \\
\hline
\end{tabular}

*: Significant at $\mathrm{p}=0.05, * *$ : Significant at $\mathrm{p}=0.01$. Mean values with the same letter are not statistically significant different from each other according to the Duncan test at $\mathrm{P} \leq 0.05$

\section{Proline and Malondialdehyde (MDA) Content Result}

Proline contents of the plants of black cumin in different plots treated with diffenet weed control applications are given in the Table 8. Prolin content of the black cumin plants ranged from 28.696 to $116.850 \mathrm{mM}$ depending on the weed control treatment. The lowest prolin content was determined in the plants grown with without weed control while highest proline content was determined in the plants grown with the post-emergent herbicide to control weeds. The plants in the plots with manuelly hoeing showed the prolin content not so much different from those grown in the control plots with without weed control. Proline is a kind of aminoacid, of which content is important to determine the stress condition and takes part to stabilise cell homeostasis in stressful conditions (Szabados and Savoure, 2010). In the studies on black cumin, the proline content of control application was found between 0-20 $\mu \mathrm{M} \mathrm{g}^{-1}$ (Fazeli et al., 2018; Fallah et al., 2018). Similarly, proline content of herbicide treated soyabean plants was markedly increased in comparison with that of untreated plants (Fayez, 2000).

MDA contents of the leaves of black cumin grown with different weed control treatments are given in the Table 8 . The values of MDA content changed between $0.46 \mathrm{nmol} . \mathrm{g}^{-}$ 1 and $1.14 \mathrm{nmol} \mathrm{g}^{-1}$ depending on the weed control treatment. The lowes value of MDA was determined in the leaves of the plants grown with without weed control while highest value of MDA content was dfetermined in the leaves of the plants grown with the tretmnet of presowing+pre-emergent+post emergen herbicide application. MDA is a result of lipid peroxidation and its elevation indicates stress-induced cell destruction (Buege and Aust, 1978). The MDA contents of control plants were recorded between 0.1-0.2 nmol.g ${ }^{-1}$ (Rozita et al., 2012: Fazeli et al., 2018). In our study, MDA content of control plants was found lower than those treated with different weed control applications.

Table 8. The Proline and MDA content of black cumin plants grown with different weed control treatment in the year of 2018 (Pr.S= pre-sowing, Pr.E=pre-emergence, Po.E= post-emergence).

\begin{tabular}{lcccc}
\hline & \multicolumn{2}{c}{ Proline $(\mathrm{mM})$} & \multicolumn{2}{c}{ Malondialdehit $\left(\mathrm{nmol.g} \mathrm{g}^{-1}\right)$} \\
\cline { 2 - 5 } Treatments & Avarage & Standard Dev. & Avarage & Standard Dev. \\
\hline Control & 22.820 & 7.50 & 0.46 & 0.11 \\
Pre-emergence & 37.211 & 20.81 & 0.59 & 0.15 \\
Post-emergence & 116.856 & 27.26 & 0.49 & 0.02 \\
Pr.S+Pr.E & 29.996 & 12.88 & 0.86 & 0.54 \\
Pr.S+Po.E & 38.784 & 8.03 & 0.67 & 0.00 \\
Pr.E+Po.E & 55.307 & 19.70 & 1.02 & 0.25 \\
Pr.S+Pr.E+Po.E & 34.364 & 8.69 & 1.14 & 0.39 \\
Manuel hoeing & 28.696 & 9.85 & 0.60 & 0.41 \\
\hline
\end{tabular}

\section{CONCLUSION}

Weeds compete with the crops and affect negatively the yield and quality of the crop. Therefore, weeds must be controlled with proper weed control method. Chemical control or control with herbicides is a widely applied weed control method. It is an important factor to select suitable herbicide and dose in accordance with dominated weeds for controlling them (Kudsk, 2008), and also soil humidity at application time and irrigation after weed control are important factors for herbicide activities. Effective minimum dose applications' activity can be optimized by considering climate conditions and weed species' sensitivity, growing high competitive crops. Optimum sowing density can be controlled weed biomass and needed further studies (Izquierdo et al., 2003: Rastegar et al., 2018). Thus, an environmentally friendly and economical 
weed control system can be constituted. At the end of study, result of this study showed that herbicides used to control up weeds was not effective to control weeds, because of weeds' high density at trial period, so the development of black cumin was influenced negatively.

\section{ACKNOWLEDGEMENTS}

This research was supported by Commission of the Scientific Research Projects of Cukurova University (P. No: FBA-2016-5412). The authors would like to thank to the financial support.

\section{LITERATURE CITED}

Abdolrahimi, B., P. Mehdikhani and A. Hasanzadeh Gort Tappe. 2012. The effect of harvest index, yield and yield components of three varieties of black seed (Nigella sativa) in different planting densities. International Journal of Agriscience 2(1): 93-101.

Ahuja, K. and S. Singh. 2019. Black seed Oil Market Share 20192025 Industry Trends Growth Report. Global Market Insights GMI3085, 280p.

Aldrich, R.J. and R.J. Kremer. 1997. Principles in Weed Management. Second. Edition, Iowa State University, Ames / Iowa, $455 \mathrm{~s}$.

AOCD. 1993. Official methods and recommended practices. AOCS, Champaign, IL.

Bates, L., R.P. Waldren and I.D. Teare. 1973. Rapid determination of free proline for water stress studies. Plant and Soil 39:205-207.

Buege, J.A. and S.D. Aust. 1978. Microsomal lipid peroxidation. In: Methods in Enzymology (Vol. 52, pp. 302-310). Academic Press.

Can, M., D. Katar, N. Katar, M. Bagci, And I. Subasi. 2021. Yield and fatty acid composition of black cumin (Nigella sativa L.) populations collected from regions under different ecological conditions. Applied Ecology and Environmental Research 19(2):1325-1336.

D'antuono, L.F., A. Moretti and A.F.S. Lovato. 2002. Seed yield, yield components, oil content and essential oil content and composition of Nigella sativa $\mathrm{L}$. and $N$. damescena $\mathrm{L}$. Industrial Crops and Products 15(2002): 59-69.

Fallah, S., S. Malekzadeh and M. Pessarakli. 2018. Seed priming improves seedling emergence and reduces oxidative stress in Nigella sativa under soil moisture stress. Journal of Plant Nutrition, 41(1): 29-40.

Fayez, K.A. 2000. Action of photosynthetic diuron herbicide on cell organelles and biochemical constituents of the leaves of two soybean cultivars. Pesticide. Biochemistry and Physiology 66:105-115.

Fazeli, A., B. Zarei and Z. Tahmasebi. 2018. The effect of salinity stress and salicylic acid on some physiological and biochemical traits of black cumin (Nigella sativa L.). Iranian Journal of Plant Biology 9(4):68-83.

Gonen, O. 1999. Determination of germination biology and morphologic characteristic to use practical identification with computer of summer growing weed species in Cukurova region of Turkey. Ins. of Natural And App. Sci. Univ. of Cukurova, $\mathrm{PhD}$ thesis, 233p.

Gutiérrez Prieto L.M.V. and S. Kirici. 2020. Effect of different irrigation levels on yield and quality of black cumin (Nigella sativa L.). C.U J. of Science and Eng. 39(10): 28-40.

Hancerli, L. and F.N. Uygur. 2017. Weed Species Infesting Corn Growing Areas in Cukurova Region. Turkish Journal of Weed Science 20(2): 55-60

Haq, M.Z., M.M. Hossain, M.M. Haque, M.R. Das and M.S. Huda. 2015. Blossoming characteristics in black cumin genotypes in relation seed yield influenced by sowing time. American Journal of Plant Sciences 6(08):1167.

Hodges, D.M., J.M. DeLong, C.F. Forney and R.K. Prange. 1999. Improving the thiobarbituric acid-reactive-substances assay for estimating lipid peroxidation in plant tissues containing anthocyanin and other interfering compounds. Planta 207(4):604-611.

Hussain, A, A. Nadeem, I. Ashraf and M. Awan. 2009. Effect of weed competition periods on the growth and yield of black seed (N. sativa L.). Pak. J. Weed Sci. Res. 15(1):71-81.

Izquierdo, J. J. Recasens, C. Fernández-Quintanilla and G. Gill. 2003. Effects of crop and weed densities on the interactions between barley and Lolium rigidum in several Mediterranean locations. Agronomie 23: 529-536.

Jin, Z.L., F. Zhang, Z.I. Ahmed, M. Rasheed, M.S. Naeem, Q.F. Ye and W.J. Zhou. 2010. Differential morphological and physiological responses of two oilseed Brassica species to a new herbicide ZJ0273 used in rapeseed fields. Pesticide Biochemistry and Physiology. 98:1-8.

Kalcin, F.T. 2003. Effect of plant density on yield and yield components on two black cumin species (Nigella sativa L., Nigella damascena L. ) (MSc Thesis), Ankara University Institute of Natural and Applied Sciences, Ankara (in Turkish).

Kirici S, E. Bayram, S. Tansi, O. Arabaci, H. Baydar, I. Telci, M. Inan, D.A. Kaya and A. Ozel. 2020. Current situation and future in the production of medicinal and aromatic plants, Turkey Agricultural Engineering IX. Technical Congress Proceedings -1:505-528 (in Turkish).

Kizil, S., S. Kirici, O. Cakmak and M. Khawar. 2008. Effects of sowing periods and $\mathrm{P}$ application rates on yield and oil composition of black cumin (Nigella sativa L.). J. Food Agr. \& Environ. 6(2): 242-246.

Kong, W., F. Liu, C. Zhang, J. Zhang and H. Feng. 2016. Nondestructive determination of malondialdehyde (MDA) distribution in oilseed rape leaves by laboratory scale NIR hyperspectral imaging. Scientific Reports 6:35393 (DOI: 10.1038/srep35393).

Korav, S., AK, Dhaka, R. Singh, N. Premaradhya and GC. Reddy. 2018. A study on weed competition in field crops. Journal of Pharmacognosy and Phytochemistry 7(4):3235-3240.

Kudsk, P. 2008. Optimising herbicide dose: a straight forward approach to reduce the risk of side effects of herbicides. The Environmentalist. 28(1):49-55.

Kudsk, P and J.L. Kristensen. 1992. Effect of environmental factors on herbicide performance. First Internatiaonal Weed Control Congress. Pp:173-186, Melbourn, Australia.

Kucukemre, D. 2009. Effects of different row spacing and seeding rates on yield and some quality properties of black cumin (Nigella sativa L.). (MSc Thesis) GOP. Univ. Institute of Natural and Applied Sciences, $67 \mathrm{p}$ (in Turkish).

Mariod, A.A., R.M. Ibrahim, M. Ismail and N. Ismail. 2009. Antioxidant activity and phenolic content of rich fractions obtained from black cumin (Nigella sativa) seedcake. Food Chemistry 116:306-312.

Meena, S.S., R.S. Mehta, R.D. Meena, R.L. Meena and D.K. Sharma. 2014. Economic feasibility of weed management practices in nigella (Nigella sativa L.). Journal of Spices and Aromatic Crops 23 (2):224-228.

Nadeem, M.A., A. Tanveer, T. Naqqash, A.J. Jhala and K. Mubeen. 2013. Determining critical weed competition periods for black seed. The J. Animal \& Plant Sciences 23(1):216-221.

Ozel, A., T. Demirbilek and I. Guler. 2002. The effect of different sowing times on the yield and some measurable results of black cumin types (Nigella sativa spp.) in Harran Plain 
conditions. Journal of the Faculty of Agriculture of Harran Univ. 6(3-4):81-90 (in Turkish).

Ozel, A., U. Demirel, I. Guler and K. Erden. 2009. The effect of different row spacing and seed quantity on yield and some agricultural characters in black cumin (Nigella sativa L.). Journal of the Faculty of Agriculture of Harran Univ 13(1):17-25 (in Turkish).

Rastegar, A. M. Zare, S. Sharafzadeh, K. Ordookhani and O. Alizadeh. 2018. The effect of planting density and weed interference on agricultural traits of different rapeseed genotypes in Darab Region using multivariate statistical methods. Nativa, Sinop, 6(3):276-287.

Rozita K., F. Hassan, N. Fatemeh. 2012. Salicylic acid ameliorates the effects of oxidative stress induced by water deficit in hydroponic culture of Nigella sativa. Journal of Stress Physiology \& Biochemistry 8(3):13-22.

Saladin, G., C. Magné and C. Clément. 2003. Impact of flumioxazin herbicide on growth and carbohydrate physiology in Vitis vinifera L. Plant cell reports. 21(8):821827.
Seyyedi, S.M., P. R. Moghaddam and M. N. Mahallati. 2016. Weed Competition Periods Affect Grain Yield and Nutrient Uptake of Black Seed (Nigella Sativa L.). Horticultural Plant Journal 2 (3): 172-180.

Steel, R.G.D. and J.H. Torrie. 1980. Principles and Procedures of Statistics. McGaw-Hill Book Company, Inc. N.Y.

Szabados, L. and A. Savoure. 2010. Proline: a multifunctional amino acid. Trends in Plant Science 15(2):89-97.

Tuncturk, M., Z. Ekin and D. Turkozu. 2005. Response of black cumin (Nigella sativa L.) to different seed rates growth, yield components and essentials oil content. Journal of Agronomy 4(3):216-219.

Tunk, S. and F.N. Uygur. 2020. Investigation of the main harmful, harmful and beneficial weed species on the label of herbicides recommended for weeds of wheat fields in Cukurova Region. Turkish Journal of Weed Science 23(1): 24-33.

Verbruggen, N. and C. Hermans. 2008. Proline accumulation inplants. Amino Acids. 35:753-759 (DOI 10.1007/s00726008-0061-6). 